\title{
A Rare Case of Epilepsia Partialis Continua Caused by a Transient Thalamic Pulvinar Lesion
}

\author{
Geçici Talamik Pulvinar Lezyonun Neden Olduğu Nadir Bir Epilepsi Partialis Continua \\ Olgusu
}

\author{
Yusuf KOÇAK ${ }^{I}$ Asuman ÇELIKBBILEK ${ }^{I}$
}

\begin{abstract}
$\underline{0 ̈ Z}$
Epilepsi parsialis continua (EPC), fokal motor status epileptikusun bir alt sınıfıdır. Kortikal bir kökene dair kanıtlara rağmen, subkortikal patolojiler - özellikle talamusla ilgili olanlar - öne sürülmüştür. Burada, daha önce bildirilmemiş olan, manyetik rezonans görüntülemede (MRG) tespit edilen, geri dönüşümlü bir pulvinar talamik lezyonu olan, fokal fasiyobrakiyal nöbetleri olan bir EPC vakasını sunuyoruz. 89 yaşında erkek hasta, üç saatlik sağ taraflı sürekli fasiobrakial nöbet aktivitesi öyküsü ile acil servisimize başvurdu. Difüzyon ağırlıklı görüntülerde pulvinar bölgede sol talamusta hiperintensite görüldü. Takip MRG, aynı bölgedeki anormal sinyalin tam kaybolduğunu ortaya koydu. Olgumuz, daha önce beyin lezyonu olmayan yaşlı bir hastada olağandışı bir lokalizasyonda geçici bir talamik pulvinar lezyonun neden olduğu EPC nedeniyle ilginçti.
\end{abstract}

Anahtar Kelimeler: epilepsi partialis continua; fasiobrakial nöbet; manyetik rezonans görüntüleme; pulvinar; talamus

\section{ABSTRACT}

Epilepsia partialis continua (EPC) is a subclass of focal motor status epilepticus. Despite the evidence for a cortical origin, subcortical pathologies-especially those involving the thalamus-have been proposed. Here, we report a case of EPC with focal faciobrachial seizures, with a reversible pulvinar thalamic lesion detected on magnetic resonance imaging (MRI), such as has not previously been reported. An 89-year-old man presented to our emergency department with a three-hour history of right-sided continuous faciobrachial seizure activity. Diffusion-weighted images showed hyperintensity in the left thalamus in the pulvinar region. Follow-up MRI revealed complete resolution of the abnormal signal in the same region. Our case was interesting because of the EPC caused by a transient thalamic pulvinar lesion in an unusual localization in an elderly patient with no previous brain lesions.

Key Words: epilepsia partialis continua; faciobrachial seizure; magnetic resonance imaging; pulvinar; thalamus

Received: 20.06.2021; Accepted: 19.11.2021

${ }^{1}$ Ahi Evran University Medical School, Department of Neurology, Kirsehir, Turkey.

Corresponding Author: Asuman Celikbilek, Ahi Evran University Medical School, Department of Neurology, Kirsehir, Turkey. e-mail: asunebioglu@yahoo.com

How to cite: Koçak Y, Çelikbilek A. A rare case of epilepsia partialis continua caused by a transient thalamic pulvinar lesion. Ahi Evran Med J. 2021;5(3):258261. DOI: $10.46332 / \mathrm{aemj} .954952$ 


\section{INTRODUCTION}

Epilepsia partialis continua (EPC) was first described in four patients by Russian neurologist Aleksei Kozhevnikov in 1894; various definitions were subsequently offered, and it was ultimately defined as a subclass of focal motor status epilepticus. ${ }^{1}$ EPC is characterized by continuous focal motor seizures confined to one part of the body, often in the face and upper extremities, for a period of minutes, hours, or days. ${ }^{1}$ EPC is mostly observed in patients with focal cerebral cortical lesions, including stroke, tumor, or metabolic disorders such as nonketotic hyperglycemia. ${ }^{2}$ However, subcortical pathologies, especially those of the thalamus, may also be included in the etiology. ${ }^{3}$ Here, we report a case of EPC with focal faciobrachial seizures in an elderly male patient, with a contralaterally reversible thalamic pulvinar lesion detected on magnetic resonance imaging (MRI), such as has not previously been reported.

\section{CASE REPORT}

An 89-year-old man was admitted to our emergency department with a three-hour history of repetitive right-sided focal motor seizures affecting his face (mouth angle and eyelid twitching) and right upper limb. He only had hypertension, which had been well-controlled with amlodipine $5 \mathrm{mg}$ per day for more than 10 years. He reported no history of fever, head trauma, sensory or vision changes, or similar episodes. He was alert and conscious, vitals were stable, and his neurological examination was normal. The right-sided focal seizure activity was reduced with a halfdose of midazolam $(7.5 \mathrm{mg}$ ) and ceased after the administration of levetiracetam (1000 mg/24h). Repeated neurological examinations revealed mild motor dysarthria after the epileptic seizure had stopped. Laboratory data was unremarkable. In an electroencephalography (EEG) performed eight hours after the patient's admission, a background slowing was noted across the entire left hemisphere without any epileptiform discharge (Figure 1).

Brain MRI, ten hours later, showed hyperintensity in the left thalamus in the pulvinar region on diffusion-weighted imaging (DWI) (Figure 2A), while no signal change was observed on the apparent diffusion coefficient (ADC) mapping (Figure 2B).

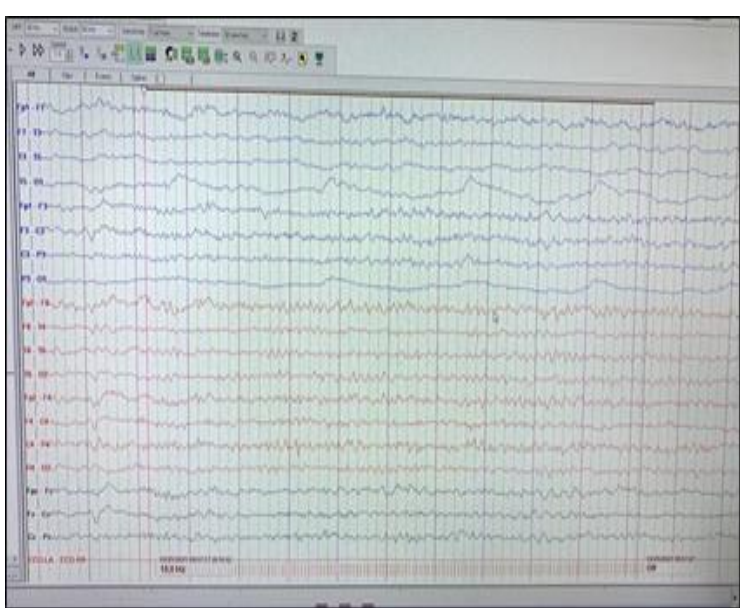

Figure 1. The EEG illustrated an asymmetric postictal slowing on the entire left hemisphere

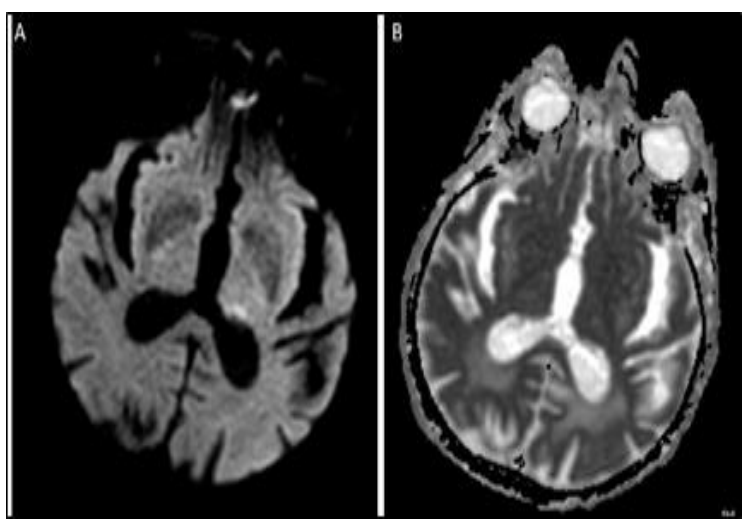

Figure 2. Brain MRI showed hyperintensity in the left thalamus at the pulvinar region on the DWI (A), while no signal change was observed on the ADC mapping (B)

Brain MRI angiography was negative for vascular pathologies. The patient's motor dysarthria resolved within 12 hours, and the patient had no more seizures after discharge. Follow-up MRI two weeks later revealed complete resolution of the abnormal signal in the thalamic pulvinar region and no neurological findings (Figure 3).

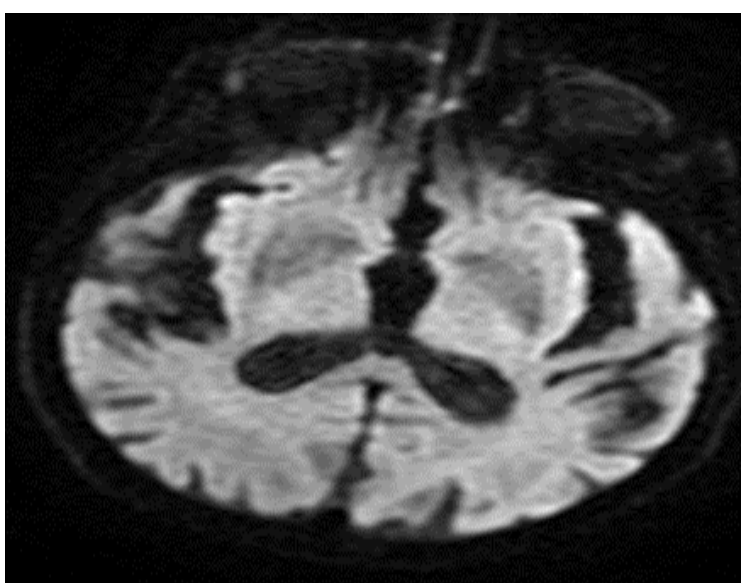

Figure 3. Follow-up MRI, after two weeks, revealed complete resolution of the abnormal signal in the thalamic pulvinar region

Informed consent was obtained from the patient. 


\section{DISCUSSION}

Many cerebral structural lesions, including stroke, tumor, trauma, or metabolic disorders such as nonketotic hyperglycemia, have been implicated in the pathogenesis of EPC. ${ }^{1}$ Although cortical pathologies are predominantly discussed, previous studies have shown that subcortical structures might be involved as well. ${ }^{3}$ Among these, the thalamus has the greatest ability to trigger abnormal discharges because of its inherent rhythmicity. ${ }^{2}$ More recent imaging studies have given insight into the involvement of the sub-domains of the thalamus. ${ }^{4,5}$ Katramados et al. analyzed the specific clinical, radiological, and EEG characteristics of patients who had acute thalamic involvement in focal status epilepticus ${ }^{4}$ and found thalamic hyperintense lesions on DWI that appeared in the region of the pulvinar nucleus, ipsilateral to the epileptiform activity on EEG. This prolonged ictal activity in the thalamic nuclei was thought to be linked to the reciprocal connections with the involved cortex. ${ }^{4}$ Similarly, Ohe et al. demonstrated pulvinar abnormalities on MRI, which may have been due to excessive activity, leading to a lowered seizure threshold through these connections in patients with focal status epilepticus. $^{5}$

In our case, a hyperintensity was detected in the left thalamic pulvinar region on DWI, contralateral to the muscles affected. Based on ADC mapping with no signal change, ischemic infarction was excluded, and cerebral MR angiography was negative for other pathologies. We noted a background slowing on the EEG across the entire left hemisphere ipsilateral to the involved lesion side. This was accepted as a postictal electrophysiological finding, offering clues to the symptomatic epileptic focus. Follow-up MRI showed a complete resolution of the abnormal signal in the pulvinar region.

It is difficult to explain the disappearance of this lesion, but we speculate that this condition could be caused by an episode of prolonged hypoperfusion or oligemia, possibly creating a tendency toward neuronal hyperexcitability. ${ }^{6}$ Underlying paroxysmal hemodynamic changes are not surprising in elderly cases, such as our patient, who has had hypertension for more than 10 years. ${ }^{7}$ Indeed, in the relationship between ictal activity and reversible thalamic lesions, there remains controversy as to which takes place first. ${ }^{7,8}$ In a report by Szabo et al. on a group of patients with focal epileptic seizures, abnormal signal changes in the hippocampus and pulvinar region on DWI were thought to be the result of prolonged ictal activity. ${ }^{7}$ Another study confirmed this finding, with MRI findings indicating both parenchymal cytotoxic and vasogenic edema as secondary to the focal motor epileptic activity in a 53year-old man. ${ }^{8}$ In contrast, we think that a left thalamic pulvinar lesion caused a right-sided continuous faciobrachial seizure activity in our patient, without a previous brain lesion. Certain regions are relatively vulnerable to hypoxic ischemia in a chronic hypertensive state, and an episode of prolonged hypoperfusion or oligemia triggering neuronal hyperexcitability could be the first condition, which would present with hyperintensity on DWI and which probably induced the continuous seizure activity.

Our patient developed mild motor dysarthria for about 12 hours after EPC, which could be attributable, as a postictal lateralizing finding, to reversible dysfunction in the connection of the affected left thalamic region to the dominant hemispheric speech area. A complicated issue arises from the occurrence of motor phenomena, such as epileptic seizures and speech problems, in the pulvinar region lesion, where mostly visual and auditory connections are located. ${ }^{6}$ The pulvinar is an associative thalamic nucleus, with numerous connections to the cerebral cortex. ${ }^{2}$ Examination of the topography of connectivity reveals that the pulvinar connection zones of nearby cortical areas overlap, which may allow the pulvinar to regulate cortical information processing. $^{2}$

In conclusion, our case was interesting because of the EPC caused by a transient thalamic pulvinar lesion in an unusual localization in an elderly patient with no previous brain lesion.

\section{Conflict of Interest}

The authors declare that there is not any conflict of interest regarding the publication of this manuscript.

\section{Authors' Contributions}

Concept/Design: YK, AÇ. Data Collection and/or Processing: YK, AÇ. Data analysis and interpretation: YK, 
AÇ. Literature Search: YK, AÇ. Drafting manuscript: YK,

AÇ. Critical revision of manuscript: AÇ. Supervision: AÇ.

\section{REFERENCES}

1. Mameniskiene R, Wolf P. Epilepsia partialis continua: A review. Seizure 2017;44:74-80.

2. Shipp S. The functional logic of cortico-pulvinar connections. Philos Trans R Soc Lond B Biol Sci. 2003;358(1438):1605-1624.

3. Cunha IA, Gomes I, Gens H, Guimarães S, Martins AI, Bento C. Sporadic Creutzfeldt-Jakob disease presenting as epilepsia partialis continua and non-ictal nystagmus. Eur J Neurol. 2021;28(7):2456-2459.

4. Katramados AM, Burdette D, Patel SC, Schultz LR, Gaddam S, Mitsias PD. Periictal diffusion abnormalities of the thalamus in partial status epilepticus. Epilepsia. 2009;50(2):265-275.

5. Ohe Y, Hayashi T, Deguchi I, ve ark. MRI abnormality of the pulvinar in patients with status epilepticus. J Neuroradiol. 2014;41(4):220-226.

6. Fernández-Torre JL, Martín-García M, Orozco-Sevilla E, Mato-Mañas D, Hernández-Hernández MA, Marco de Lucas E. Epilepsia partialis continua and cortical motor control: insights into physiology. Epileptic Disord. 2019;21(6):603-607.

7. Szabo K, Poepel A, Pohlmann-Eden B, ve ark. Diffusion-weighted and perfusion MRI demonstrates parenchymal changes in complex partial status epilepticus. Brain. 2005;128(6):1369-1376.

8. Senn P, Lövblad KO, Zutter D, ve ark. Changes on diffusion-weighted MRI with focal motor status epilepticus: case report. Neuroradiology. 2003;45(4):246-249. 